\title{
Quasi nani super humeros gigantum? Reusing Classical and Medieval Quotations in the Hagiographic Discourse in Tenth- Century Liège
}

Sibil Gruntar Vilfan* and Cristian-Nicolae Gaşpar ${ }^{\star \star}$

INTRODUCTION - THE SCHOOL OF LIÈGE AT THE TIME OF THE OTTONIAN RENAISSANCE AND RHYMED PROSE: VITA REMACLI II

The tenth century has been known under many names and described variously as "post-Carolingian," "pre-Gregorian," "the iron century," and "the dark century." Some see it as a period of literary and intellectual decline. ${ }^{2}$ However, instead of focusing on the search for adequate terminology to describe it, it would be better to perceive the tenth century as an age of intellectual transition, especially when seen from the perspective of the better-known periods of flourishing intellectual life that preceded or followed it. Furthermore, there has recently

* Swansea University; gruntar-vilfan_sibil@alumni.ceu.edu.

**Central European University; gasparc@ceu.edu.

1 Leonardi, "Intellectual Life," 186. The titular simile, quasi nani super humeros gigantum, is from Neckam, De Nat. rer., 1.78.24-25.

2 Baronius, Annales ecclesiastici, 467; Contreni, Carolingian Learning, Masters and Manuscripts, 380; Grotans, Reading in Medieval St. Gall, 3; Haskins, Renaissance of the Twelfth Century, 16. 
been a more nuanced assessment of the tenth century, referring to it with the term of the Ottonian Renaissance, which emphasizes the cultural and intellectual development of the era and avoids previous pejorative designations. ${ }^{3}$

One of the main centres of the Ottonian Renaissance, apart from the court in Aachen, was the area of Liège, especially its cathedral school and the intellectual circle around Notger (940-1008), the first prince and bishop of Liège. ${ }^{4}$ The cathedral school of Liège at the time of the Ottonian Renaissance produced hagiographical texts that display one of the main characteristics of the Ottonian Renaissance, i.e. building a new piece of art with extensive use of various ancient elements..$^{5}$ In the Latin prose texts created during the time of the Ottonian emperors, this creative strategy is reflected in the extensive use of quotations from classical authors and the Bible and Christian authors. Such quotations were used as textual building blocks. ${ }^{6}$ At the same time, the use of rhymed prose emerged as a fashionable stylistic convention in Latin prose. The Ottonian Renaissance and the emergence of rhymed prose gave rise to the creation of remarkable Latin hagiographic prose text known as the Vita Remacli Secunda (Vita II) [Bibliotheca Hagiographica Latina (BHL) 7115, 7116].

Vita II is one of the most representative texts associated with Liège, where it was also produced. The modern conventional name suggests that this is the second Vita written about St. Remaclus. He was a seventh-century bishop (d. 673), who founded the abbey of Malmedy in the bishopric of Cologne and not long afterward also the abbey of Stavelot, a few kilometers west of Malmedy.7 As an abbot, he decided to live the rest of his life in the abbey of Malmedy, where he also died. ${ }^{8}$ The two abbeys kept fighting for the "ownership" of the saint's cult until, in 938, both came to be ruled by a single abbot. ${ }^{9}$ In these circumstances, the abbot of the imperial monastery of Stavelot, Werinfrid (954-980),

3 Jacobsen, "Formen und Strukturen der lateinischen Literatur," 917-49; McKitterick, "Continuity and Innovation," 15-24; Head, Hagiography; Bayer, "La Vita."

4 Wilkin and Kupper, "Introduction," 12; Kurth, Notger, passim.

5 A helpful discussion of the use of quotations in medieval texts (and of spolia in medieval art) is available in the various studies collected in the volume Ideologie e pratiche del reimpiego nell'alto medioevo (Eco, 461-484; Kinney, 233-52).

6 The result of such use of classical and Christian spolia (Spolientechnik) is what Walter Berschin calls Ottonischer Schmuckstil. See Berschin, Biographie und Epochenstil, vol. 4.1, 100-1, 127, 157.

7 Thomas, Butler's Lives of the Saints, 26.

8 Ibid.

9 Ibid. 
requested from Notger, bishop of Liège (972-1008), to revise the existing saint's life, now commonly referred to as Vita Remacli $I^{10}$ When the Vita II was finished, sometime between 972 and 980, it was prefaced by a letter in Notger's name. ${ }^{11}$ At that time, Notger's secretary was the abbot of Lobbes, Heriger, most probably responsible for drafting much of Notger's correspondence. ${ }^{12}$ The two men worked closely together, and to this day, there is an intense dispute among scholars regarding the authorship of Vita II. ${ }^{13}$

When analyzing a text of such stylistic, contextual, and content complexity as displayed in the Epistula and Vita II, it is worth addressing it from different perspectives. This paper will focus on three aspects: the quotations from classical and medieval authors, rhymed prose, and manuscript tradition. How were the quotations from classical and Christian sources modified when included in the new text? To what degree were they adapted to the rules of rhymed prose? What patterns of the rhymed prose are discernible in the text? Was the quotation's meaning altered when included in the new (con)text?

The aim of the present article is therefore threefold. First, to show how the later Vita Secunda Sancti Remacli (Vita II) and its preface, i.e., The Letter to the Abbot Werinfrid of Stavelot (Epistula), written in the area of Liège in the tenth century, use quotations from ancient and Christian sources. These were not merely petrified forms of lifeless ancient wisdom but rather raw gems that were polished to fit into the new linguistic framework of rhymed prose. Thus, quotations played a double role: they enriched both the form of the text and its content, closely connected to the cultural and political context of the age. ${ }^{14}$ Second, to point out that the old nineteenth- and twentieth-century editions of this text are likely to act as distorting mirrors for the modern reader, since they, in keeping with the common practice of that time, did not always pay attention to the role of the classical quotations reemployed in medieval texts where they were subjected to the rules of rhymed prose. Third, the last part of the article suggests an alternative way of editing similar hagiographic texts written in rhymed prose, where the quotations of classical and medieval authors are placed in their proper context considering the manuscript tradition, stylistic

10 Webb, “The Decrees," 33; Snijders, “Obtulisti libellum," passim.

11 Ibid.

12 Ibid, 34.

13 Ibid.

14 For stylistic and content analysis, see Gruntar Vilfan, Quasi nani super humeros gigantum, 2017. 
rules that governed the use of rhymed prose, and the multi-functional role that these quotations had in the new linguistic framework. In this way, it would become even clearer that whoever the author(s) of the Epistula and Vita II was or were, their work would not have been possible without the great writers who came before and that they, indeed, were "standing on the shoulders of the giants." ${ }^{15}$

\section{PREVIOUS SCHOLARSHIP AND THE VITA REMACLI II}

The scholars who have dealt with the Vita Remacli II have so far focused on the questions of its authorship, the context of the rewriting of the earlier Vita Remacli [BHL 7113, 7114], which served as the basis for the Vita II, and the function played by St. Remaclus' cult at the abbey of Stavelot-Malmedy, which claimed him as its founder.

However, the studies on the text have focused less on its formal features or structure, especially its extensive use of rhymed prose and the wealth of quotations from earlier sources that it contains. The study of the stylistic features of the Vita II is necessary because it can help shed light on some of the intellectual practices that informed the composition of hagiographic material produced in the area of Liège, thus reflecting the intellectual and literary achievements of the cathedral school of Liège at the end of the tenth century. Furthermore, such research may contribute to the ongoing discussion on the authorship of Vita II. It should be noted that the existing studies on the use of rhymed prose in medieval texts, and more specifically, in hagiographic material, remain rare.

One of the few scholars who studied rhymed prose in detail was Karl Polheim. ${ }^{16}$ His work, however, rather than offering a systematic discussion of rhymed prose as a stylistic feature of medieval prose, consists of individual chapters dedicated to several chosen texts, whose use of rhymed prose it analyses in detail. These include various works by Hrotsvitha of Gandersheim, the Vita Mathildis reginae, the Chronicle of Gallus Anonymus, and charters. A historical overview of the development of rhymed prose is also included. The only recent author who has carried out extensive research on rhymed prose in medieval hagiographic texts is Anne-Marie Turcan-Verkerk. ${ }^{17}$ She traced the beginning of rhymed prose to the works of Gregory the

Neckam, De Nat. rer., 1.78.24-25.

Polheim, Lateinische Reimprosa.

Turcan-Verkerk, "Forme et réforme." 
Great, which offered possible inspiration and models for later usage. According to most scholars, the use of rhymed prose as a stylistic device in Latin texts peaked in the eleventh and twelfth centuries. ${ }^{18}$ The texts analyzed here, the Vita II and the Epistula, date back to the late tenth century. Despite their relatively early date, they both display a high literary style and an already very sophisticated use of rhymed prose.

\section{THE EPISTULA AND VITA II AND THEIR USE OF ANCIENT TEXTUAL MATERIAL}

In what follows, let us look at the way in which textual material from ancient and Christian sources is reused by the author of the prefatory Epistula to the Vita II.

Epistola ad Werinfridum abbatem Stabulensem ${ }^{19}$

$\begin{array}{lll}2 \underline{\text { Omnis antiquitas ut ait oratorum maximus }} & \mathrm{x} & 7 \\ \text { quo propius aberat } & \text { b } & 8 \\ \text { ab ortu et divina progenie } & \mathrm{c} & 9 \\ \text { hoc melius ea fortasse } & \mathrm{c} & 10 \\ \text { quae erant vera cernebat. } & \text { b } & 11\end{array}$

$\begin{array}{lll}3 \text { Verum angelo Danieli narrante novimus } & \mathrm{x} & 12 \\ \text { quia pertransibunt plurimi et multiplex erit scientia } & & 13 \\ \text { in antiquis utique vigente } & \text { b } & 14 \\ \text { ratione veritatis indagatrice } & \text { b } & 15 \\ \text { et perspicacia futurorum } & \mathrm{c} & 16 \\ \text { in modernis vero fide } & \text { b } & 17 \\ \text { credulitatis quamprimum pollente } & \text { b } & 18 \\ \text { cum plurima scientia praeteritorum. } & \text { c } & 19\end{array}$

18 Tunberg, "Prose Style and Cursus," 112.

19 Krusch, Monumenta Germaniae Historica (MGH) ss rer. Merov. 5 (1905), 109. In the Latin text, the verbatim quotes from various sources are given in italics, underlining has been used for those parts where the original quote has been remodelled to a degree. The last column shows the numbering of cola that does not appear in Krusch's edition. The entire Epistula is divided into 32 paragraphs in the modern editions, three of which $(2-4)$ are analyzed here. 
4 Illis diuturnitas vitae vetustatis obducens callum

cognitionem praestitit omnium rerum

nobis contra quos calidus sanguis

quos rerum inscitia versat

utinam non avolet

b 24

ob brevem vitam et curam sollicitudinum

antiquorum memorare inventa virorum!

a2 26

All antiquity as the greatest among the orators said the further away it was

from the source and the divine origin

the better those things, perhaps,

it could perceive which were true.

But we learn from the angel who revealed to

Daniel that many shall cross over and the knowledge shall be manifold.

In ancient times certainly there flourished reason and seeking of the truth speculating about the future in modern times, however, the faith of [our] belief is first and foremost strong with an abundance of knowledge about the past.

To them a long-lived life by the hardening effect of time gave knowledge of all things.

As for us, however, driven by hot blood and ignorance of the world I wish our short lifespan and everyday worries should not distract us from remembering the achievements of the ancients. 
The origin of the quotation

Cic., Tusc. Disp. 1.12.26

omni antiquitate, quae quo propius aberat $\mathrm{ab}$ ortu et divina progenie, hoc melius ea fortasse quae erant vera cernebant.

Dan. 12:4

pertransibunt plurimi, et multiplex erit scientia

Aug., Epist. 187.57.7

credulitatis fidem

Cic., Tusc. Disp. 3.22.53

quorum animis diuturna cogitatio callum vetustatis obduxerat

Hor., Ep. 1.3.33

seu calidus sanguis seu rerum inscitia vexat
Epistula

Omnis antiquitas ut ait oratorum maximus quo propius aberat ab ortu et divina progenie hoc melius ea fortasse quae erant vera cernebat.

pertransibunt plurimi et multiplex erit scientia

fide credulitatis

Illis diuturnitas vitae vetustatis obducens callum

quos calidus sanguis

quos rerum inscientia versat

The Epistola ad Werinfridum abbatem Stabulensem, which prefaces the Vita II, serving as an introduction into the subject of a religious nature, starts with a quote from Cicero. The quote is not from Cicero's rhetorical writings, but from one of his philosophical works, the Tusculanae Disputationes. This prefatory quote creates the framework for the text and may have been intended to remind the reader of the classical style and the philosophical meaning of the original. The quote is altered to make it fit into the scheme of rhymed prose, thus making it instrumental to the grander scheme of the narrative. It expresses the idea that the entire Antiquity was as close to the true nature of things as further away it was from the divine source and origin, which is in sharp contrast to how truth is perceived in Christianity because truth comes from closeness to God, not from temporal distance from him.

The next sentence introduces the immovable word of God through the words of the Prophet Daniel in marked contrast to the previously cited pagan authority. The quote from Daniel 12:4 
suggests the image of apocalyptic visions, but these visions, as they came from God, are not false or to be doubted. This biblical quote was not altered to fit into the scheme of rhymed prose. Instead, it provides a colon of its own, ending with scientia, "knowledge," which does not rhyme with any of the following or previous cola and stands out in isolation as an "orphan member." ${ }^{20}$ This and the previous sentence serve as a prelude to the fundamental philosophical and religious idea the author would express in the next section of the Epistula.

The reader is faced with a powerful opposition between the ancient (in antiquis) and the modern world (in modernis), the world of the tenth century. This contrast is vividly marked in the structure of the text because in antiquis spans cola 14-16 and in modernis cola 17-19. What is more, the two contrasting phrases rhyme with each other, creating a dynamically intertwined relationship. As the text continues, there is a rhyme at the end of colon 14 and colon 15 , namely vigente and indagatrice, and a rhyme across cola 14 and 15 vigente and ratione. This connects the two cola more closely together and, at the same time, creates an internal rhyme inside colon 15 between ratione and indagatrice, which embrace the word veritatis. This subtle structure reflects the meaning itself. In antiquity, people had to rely on the flourishing - vigente - of reason, ratione, and they had to seek - indagatrice - for the truth, veritatis. What is more, they had to try and foresee the future, to predict it as the text implies by using the phrase perspicatia futurorum, "speculating about the future." In colon 17, in modernis first echoes in antiquis, setting itself as the mirror to the ancient times. At the end of colon 17 , the word fide, which rhymes with vigente and indagatrice from cola 14 and 15, invokes faith in God as opposed to the merely human searching for meaning. Faith is something firm, something one can rely on while searching is uncertain. This very faith is based on the Christian belief in the word of God, while the search for meaning practiced by the ancients is something quite different and based on human reasoning. In addition to this, the use of the words pollente to describe fide and vigente to describe ratione, which rhyme across cola 17-18 and 14-15 respectively, emphasizes the contrast between fides and ratio. one may also refer to such non-rhyming cola as "stray members," which stand out from the regular system of rhyming cola used in texts that employ rhyming prose. 
In the past, reason was, as the word vigente suggests, alive, thriving, flourishing, which implies it is also something which inevitably will die, as all living things do. However, the word describing faith, pollente, suggests this is potent and durable, not something with a beginning and an end as that of all living things. Faith is eternal. However, in modern times, people have the faith of their belief and the abundance of knowledge of the past expressed as plurima scientia praeteritorum, "an abundance of knowledge about the past," which again recalls perspicatia futurorum from colon 16 above, making a double rhyme across the cola 16 and 19, so as to emphasize this. The very word scientia looks back to the biblical quote in which scientia was multiplex, suggesting that the knowledge of the past that people have in modern times is not the speculative knowledge of the ancients but the unique knowledge from God as revealed in the Bible.

The biblical quote was not changed according to the stylistic demands of rhymed prose. One could appropriate the way the ancients' message was uttered because it was speculation, based on causality and, therefore, subject to change and reshaping. However, the word of God, which contained the eternal, unchangeable truth, was not to be touched.

The text continues with another opposition between illis, i.e., the ancients, and nobis, i.e., the Christians in the tenth century, again creating a rhyme across cola 20 and 23 . Colon 20 introduced by illis concludes with vetustatis creating an internal rhyme. The idea presented here is that the ancients had to live a long life to be able to acquire, praestitit, the understanding, cognitionem, of things, omnium rerum. The antagonism between then and now is firmly established by the word econtra following nobis. However, this antagonism, which is embedded in the meaning of the text, is further emphasized with two rhymes across cola 20 and 22. The first one, already mentioned, connects the beginnings of cola 20 and 22, illis - nobis, and the second one connects the middle of colon 20 and the ending of colon 22, vetustatis - sanguis, adding coherence and internal logic to the text.

What follows is a wish to remember, utinam memorare, which contrasts the longevity of old with the brevity of modern life and the worries that beset it, and the acquired knowledge of things from the past with passions, calidus sanguis, and ignorance, inscientia, of today. This message, in the center of which stands colon 23 ending with versat, rhyming with aberat and cernebat from cola 8 and 11, a cross-reference to the very beginning, is in dialogue 
with the message from the previous sentence, where modernity was said to possess scientia praeteritorum. The author of the text expresses a wish that the discoveries, inventa, i.e., the knowledge of the ancients, antiquorum virorum, would not fade away from modern times, precisely because the moderns do not have a long life which would allow them to come to those discoveries. Again, the use of rhymed prose supports the internal structure. Brevem in colon 25 of this sentence rhymes back with cognitionem in colon 21, and the last two cola end with the rhyming antiquorum and virorum.

The speech of the dying saint

(Exhortacio 10-12, cola 93-111) ${ }^{21}$

$10 \mathrm{Ab}$ omnibus quae ira fieri amat temperate,

a 93

quia verum est solum esse

b 94

triumphum innocentiae,

a 95

non peccare,

a 96

ubi liceat posse.

b 97

11 In optimis quoque et adiudicantes

a 98

temperantes estote,

x 99

quia est modus in rebus;

x 100

sunt certi denique fines

a 101

quos ultra citraque nequit consistere verum.

X 102

12 Metiri se quemque suo modulo ac pede verum est.

a 103

Nemo iniuriosus sit alteri,

b 104

quia accipere quam facere praestat iniuriam.

x 105

Pacientiam, quae miseriarum portus est,

a 106

amplectimini;

b 107

quoniam nemo adeo ferus est,

a 108

ut non mitescere possit,

x 109

si modo culturae pacientem

c 110

commodet aurem.

C 111 the version of the Vita Remacli Secunda [BнL 7116], which has been transmitted individually, not as part of the Gesta. The ready availability online of the three mss. of BHL 7116, which had been used by previous editors, made it easier to work with both mss. and critical editions. The last column shows the sequential numbering of cola that does not appear in the critical edition. 
Beware of that which anger is in the habit to love for the truth is that innocence is victorious only then when sin has not been committed even though the opportunity presented itself.

Do not lose your better judgment even in the most pleasant things, be modest for there is a limit in things and a firm boundary beyond which truth cannot exist.

It is only true that each is his own measure. No one is to be unjust to the other for it is far better to receive injustice than to inflict it.

Accept patience that is a shelter from the storm for no one is so ferocious that could not be tamed if they only patiently open their ear to education.

Sal., De Bello Iug. 34.1.83 atque aliis omnibus, $\underline{\mathrm{Ab} \text { omnibus quae ira fieri }}$ quae ira fieri amat amat temperate,

[Dictum quoted by several authors ${ }^{22}$ and attributed either to Plato or to Aristotle] Triumphus innocentiae $\underline{\text { solum esse }}$ est non peccare ubi liceat posse triumphum innocentiae, non peccare, ubi liceat posse

22 See, for instance, the Benedictine theologian Heiric d'Auxerre (841-876), Collectanea di Eirico, 135, 12. 
Hor., Serm. 1.1.105-106

est modus in rebus, sunt certi denique fines / quos ultra citraque nequit consistere rectum.

Hor., Ep. 1.7.98

metiri se quemque suo modulo ac pede verum est.

Cic., Tusc. Dis. 5.19

accipere quam facere praestat iniuriam

Hor. Ep. 1.1.39-40

nemo adeo ferus est ut non mitescere possit, / si modo culturae patientem commodet aurem est modus in rebus;

sunt certi denique fines

quos ultra citraque nequit consistere verum

Metiri se quemque suo modulo ac pede verum est

accipere quam facere praestat iniuriam

nemo adeo ferus est, ut non mitescere possit, si modo culturae pacientem commodet aurem

This passage of the Vita II, referred to here as the Exhortacio, contains Remaclus' deathbed speech full of admonitions, suggestions, and exhortations to his fellow monks. The entire speech comes through as an address full of Christian zeal couched in the words of both ancient pagan writers and Christian authors. Pagan and Christian thought are skillfully intertwined, leaving aside any dichotomy which might arise from the religious allegiance of the authors quoted. The segment where this is illustrated most vividly is represented by paragraphs 10 to 13 of chapter 21 of the Vita II. Paragraph 10 starts with a warning to the monks to stay away from everything that anger loves, which echoes the words of Sallust's Bellum Iugurthinum. The military context of pagan antiquity is then replaced with the Christian metaphor of a monk as Christ's soldier. In the following sentence, this is further reinforced with the choice of the word triumphus, emphasizing that the only triumph of innocence is not to sin, although there was an opportunity. The idea and its formulation were most often attributed to Plato (for instance, in the compilation of philosophical sayings, Sententiae philosophorum, attributed to Caecilius Balbus and transmitted in Heiric of Auxerre's compilation Collectanea). Here the rhyme esse - posse frames the message, which also contrasts the two opposing concepts, innocentiae and peccare, connected by the same rhyme.

Next comes a quote from one of Seneca's philosophical letters, which states that not only in bad things, such as anger, but also in 
good ones, one needs to have a measure. This connects seamlessly with Horace's famous dictum that there is a measure for everything. There is even an internal rhyme between adiudicantes and temperantes, which then rhymes with fines in the second part, thus serving as a link and creating coherence. The quotation from Horace remains almost unchanged and is incorporated so that the rhyme comes naturally.

Then follows a verbatim quote from Horace's Letters illustrating the idea that everyone must measure their step, meaning that no one is to compete with another. Furthermore, no one is to be harmful to another person because it is far better to receive an insult than be the cause of one. This is reminiscent of Christ's teaching about turning the other cheek. However, this wisdom comes from a pagan authority, namely, Cicero, rather than the Bible. Cicero's quote is skillfully connected with the author's thoughts by another internal rhyme between iniuriam and pacientiam, stressing the antagonism of the meaning. The author's own words ending in est and amplectimini are connected through the rhyme to the quotation from Horace, which ends in est, and the author's own words ending in alteri.

The next verbatim quote from Horace is introduced by the conjunction quoniam, connecting the idea of patience from the previous colon with the idea that everybody can be softened if they offer a patient ear to advice and education. The word est in the colon 108 rhymes back with the two identical verbal forms in two previous cola, while pacientem in the quote rhymes with aurem as the last word of the quote.

\section{REVIEW OF EXISTING EDITORIAL PRACTICES}

To show why, in our opinion, modern editorial practices do not do enough credit to the original text, one first needs to look at the manuscript tradition of the texts discussed here and their critical editions. The latest critical edition of the Epistula is that published by Bruno Krusch. ${ }^{23}$ This edition was based on three manuscripts, namely Vatican, Reg. lat. 615; St. Gallen, Stiftsbibliothek Cod. Sang. 565; St. Gallen Stiftsbibliothek Cod. Sang. 571. Krusch based his edition on the Vatican manuscript, which he compared with the two St. Gallen manuscripts; these have similar text versions and are probably related.

Vita II has been transmitted in two ways, namely as part of the Gesta [BHL 7115] and individually as a separate text [BHL 7116]. BHL 7115 was edited by Rudolph Köpke; his edition was then reprinted in 
Migne's Patrologia Latina. ${ }^{24}$ BHL 7116 was first edited by Laurentius Surius; his edition was also reprinted in Migne's Patrologia Latina. ${ }^{25}$

Krusch's approach to editing the text illustrates the importance ascribed to classical Latin quotations, which he printed in italics, separating them visually from the rest of the text. He also distinguished between prose and verse in terms of visual representation of quotations. He kept the prose quotations as part of the text while indenting the verse quotations as separate units. Furthermore, Krusch provided references to the source of a particular quotation, i.e., the author, the title of the work, and the textual division, without going into a detailed analysis of all the textual changes which allowed the author of the Epistula to rework such quotations into the framework of the rhymed prose which structures his text. In accordance with the practice of most modern editors, Krusch's punctuation of the Latin text completely disregards the use of rhymed prose in the text of the Epistula, thus obscuring the rhymed prose's very existence. ${ }^{26}$

\section{PROPOSAL OF A NEW EDITORIAL PRACTICE}

In contrast to Krusch's editorial practice, the manuscripts used for his edition handled textual material borrowed from classical Latin authors and the system of rhymed prose, which informed the structure of the text in very different ways. In the ms. Vatican, Reg. lat. $615,{ }^{27}$ the beginning of every sentence is marked with a gold capital letter, and punctum separates parts of sentences. The use of punctum does not correspond to modern punctuation usage, but follows medieval practice based on reading the texts aloud in monastic contexts, which, in many places, coincides with the divisions created by the use of rhymed prose. ${ }^{28}$ As expected, quotations of classical and medieval authors are not marked in any particular way in the text and do not stand out. Both manuscripts from Switzerland show similar characteristics, the difference being the absence of gold capital letters at the paragraph incipits. In the St. Gallen mss., punctum was used in the same way as in the Vatican ms.,

Gesta pontificum, MGH SS 7 (1846), 166-189; Migne, PL, vol. 139, coll. 1043-46.

L. Surius, De probatis Sanctorum historiis: partim ex tomis Aloysii Lipomani ... partim etiam ex egregiis manuscriptis codicibus ...: nunc recens optima fide collectis, vol. 5 (Köln, 1574), 17-29; J. P. Migne, PL, vol. 139, coll. 1149-68.

For a detailed discussion of such editorial practices, see Turcan-Verkerk, "Forme et réforme," vol. 1, 32-40.

Accessed online at the DigiVatLib.

Grotans, Reading in Medieval St. Gall, 153. 
although it was not always placed at the same point in the text, and the quotations of classical and medieval authors were, again, not marked.

In our opinion, in order to bring the original text closer to the reader and reveal its complex composition, a novel approach to the editorial practices of hagiographic texts that include classical and medieval quotations and rhymed prose would be needed. ${ }^{29}$ The present study offers just an example of such an editorial (and hermeneutic) approach for the selected passages from Epistula and Vita II. The two passages are transcribed and divided into cola according to the system of the rhymed prose which structures the text of the original. In our presentation of the text by cola, which follows the guidelines proposed by Polheim,$^{30}$ modern editors' conventions of punctuation, capitalization, and division of the text were ignored.

Rhymed prose is commonly defined as prose divided into cola with end rhyme. Latin rhymed prose was initially (and remained, for the most part,) monosyllabic, i.e., characterized by the phonetic identity (or, at least, similarity) of the final syllable of the cola involved. The emergence of two- and three-syllabic rhyme represents a later development. ${ }^{31}$ The division of the text proposed here follows, in general, Polheim's understanding of rhymed prose. It is, however, possible that other readers might suggest alternative divisions of the same text. Our practice was to identify, as far as possible, anything susceptible of being interpreted as rhymed cola. When rhyme occurs at the end of the different cola within the same section of the text, it is marked in bold letters. However, if rhyme occurs between the end of one colon and the beginning of the next or between two consecutive cola it is marked by double underlining.

The present analysis also includes a line-by-line survey of the quotations contained in the text. The differences between the original form of the passage quoted and the form of the text re-employed in the Vita II have been pointed out, as well as the discrepancies between the edited text and the manuscripts in those cases where it appears that the modern editors' choice has disregarded the conventions of rhymed prose followed by the author of the original text. In the Latin text as presented here, the verbatim quotes from various sources are given in italics and underlining has been used for those parts where the original quote has been remodelled to a certain degree. ples, Berschin, Biographie und Epochenstil, 4.1, 67, 119, 123.

30 Polheim, Lateinische Reimprosa, 9.

31 Polheim, Lateinische Reimprosa, 9. 
Edited and interpreted in this way, the hagiographic text is more likely, we believe, to reveal not just its intricate formal structure, but also, its underlying ideological content. Rhymed prose and the formal divisions it imposes on the text contribute to the effective articulation of its message. The quotations form various sources are not simply re-shaped so as to formally fit the new context, but also re-purposed in order to articulate an original new meaning. Such quotations are not important in themselves and as they stand on their own, but rather to the extent and because of the way in which they have been stylistically and semantically integrated into the new text.

\section{CONCLUSION}

As the analysis of the quotations, rhymed prose, and their relation to the actual content of the text of selected passages from the Epistula ad Werinfridum and Vita II has shown, both texts are embellished with passages and fragments taken from other classical and medieval Latin texts. It can be argued that one of the primary motivations for this compositional strategy was to make the text more modern, especially if compared to the earlier hagiographic production that it was rewriting, the Vita I Remacli. The resulting text was modern in the way that it was more up to date ideologically and followed better the stylistic conventions that informed other hagiographic texts (but not exclusively) produced during the late tenth century in the diocese of Liège. Such a stylistic upgrading had been requested expressely by Abbot Werinfrid, who commissioned the text of the new vita from Notger of Liège. ${ }^{32}$

Our analysis of two passages of this text, limited as it is, could not illustrate the entire wealth of the sources quoted in Epistula and Vita II, which goes far beyond the few names mentioned here. It is clear, however, that such quotations were systematically re-employed either as verbatim or as remodeled quotes, regardless of their origin. Moreover, this was done in a way that, with few exceptions, made them conform to the pattern of rhymed prose. Significantly, it is the quotes from the Bible which tend not to be adapted and are incorporated into the text in their original form. This suggests that a quote from the Bible seems to represent the words of God, which makes such changes unacceptable. The quotes from the authors of antiquity, on the other hand, undergo the necessary degree of change 
to adapt them to the strictures of rhymed prose and a meaning in tune with the message of the text.

A detailed reading of Epistula and Vita II has shown that, for the author of this hagiographic text, rhymed prose was not only a stylistic convention but a way of building the structure of the text and ensuring its coherence. The meaning is intertwined with the form, often changing the sense of the original quotation in order to make it fit into the new context. The governing system of rhymed prose and the way Latin quotations have been appropriated to fit into this system seem to be applied consistently and in the same manner in both texts. This would argue in favor of a single authorship for both the Epistula and the Vita II. However, whether this single author is Heriger of Lobbes or Notger of Liège is impossible to tell.

Furthermore, in order to better illustrate and appreciate how skillfully the text was composed in keeping with the intellectual trends of the Ottonian Renaissance and the emergence of rhymed prose, a novel approach to the editorial practices applied to such texts is needed. According to this approach, the text should be divided into cola following the principles of rhymed prose rather than modern conventions of punctuation, capitalization, and division of the text. The rhyme, either end rhyme or rhyme across cola, should be clearly marked and textual quotations identified, not just in terms of their original sources, but also, as much as possible, with respect to the degree to which they have been adapted to become part of the new text.

Whoever the author of Epistula and the Vita II was, he was remarkably learned in both the Christian scriptures and the great authors of classical antiquity. His skill at integrating expressions of both classical and Biblical wisdom in the novel stylistic form of the rhymed prose is indisputable, just as indisputable as the fact that he could not have achieved his masterpiece without the luminaries who came before him. In this sense, he was indeed "standing on the shoulders of the giants." 


\section{BIBLIOGRAPHY}

\section{Primary Sources}

Baronius, Caesar. Annales ecclesiastici. Vol. 15. Ed. Augustin Theiner. Paris: Bar-le-Duc, 1868.

Donatus. "Vita Trudonis." In $M G H$ ss rer. Merov. 6, edited by B. Krusch and W. Levison, 274-28. Hannover, 1913.

Heiric d'Auxerre. I Collectanea di Eirico di Auxerre, edited by Riccardo Quadri. Fribourg: Edizioni Universitarie Friburgo, 1966.

Heriger / Notger. "Epistula ad Werinfridum abbatem Stabulensem.” In MGH Ss rer. Merov. 5, edited by B. Krusch and W. Lewison, 109-111. Hannover, 1910.

—_. "Vita Remacli Secunda." In MGH ss 7, edited by R Köpke, 180-189. Hannover, 1846.

—. "Vita Remacli Secunda." In De probatis Sanctorum historiis: partim ex tomis Aloysii Lipomani ... partim etiam ex egregiis manuscriptis codicibus ... : nunc recens optima fide collectis. Vol. 5, edited by Laurentius Surus, 17-39. Köln, 1574.

Neckam, Alexander. "Alexandri Neckam De naturis rerum libri duo: With the Poem of the Same Author, De laudibus divinae sapientiae," edited by T. Wright. London, 1863.

\section{Literature}

Bayer, Clemens M. M. "La Vita Handelini de Notger de Liège et la protohistoire de l'abbaye de Celles." In Éveque et prince: Notger et la Basse-Lotharingie aux alentours de l'an mil, edited by Alexis Wilkin and Jean-Louis Kupper, 403-84. Liège: Presses Universitaires de Liège, 2013.

Berschin, Walter. Biographie und Epochenstil im lateinischen Mittelalter. Vol. 4.1, Ottonische Biographie: Das hohe Mittelalter 920-1220. Stuttgart: A. Hiersemann, 1999.

Contreni, John J. Carolingian Learning, Masters and Manuscripts. Aldershot: Ashgate, 1992.

Eco, Umberto. "Riflessioni sulle tecniche di citazione nel medioevo." Ideologie e pratiche del reimpiego nell'alto medioevo.

Settimane di Studi del Centro Italiano di Studi sull'Alto Me- 
dioevo 46. Spoleto: Centro Italiano di Studi sull'Alto Medioevo, 1999. 461-84.

Grotans, Anna A. Reading in Medieval St. Gall. Cambridge: Cambridge University Press, 2006.

Gruntar Vilfan, Sibil. "Quasi nani super humeros gigantum?

Reusing Classical and Medieval Quotations in Hagiographic Discourse in the Area of Liège (1oth century)." MA Thesis, Central European University, 2017.

Haskins, Charles Homer. The Renaissance of the Twelfth Century. Cambridge: Harvard University Press, 1955.

Head, Thomas. Hagiography and the Cult of Saints: The diocese of Orléans, 800-1200. Cambridge: Cambridge University Press, 1990.

Jacobsen, Peter Christian. "Formen und Strukturen der lateinischen Literatur der ottonischen Zeit." Il secolo di ferro: mito e realtà del secolo X. Settimane di Studio del Centro Staliano di Studi sull'Alto Medioevo, 38. Spoleto: Centro Italiano di Studi sull'Alto Medioevo, 1991. 917-49.

Kinney, Dale. "The Concept of Spolia." In A Companion to Medieval Art: Romanesque and Gothic in Northern Europe, edited by C. Rudolph, 233-52. Oxford: Blackwell, 2006.

Kurth, Godefroid. Notger de Liège et la civilisation au xe siècle. Brussels: A. Picard, O. Schepens, L. Demarteau, 1905.

Leonardi, Claudio. "Intellectual Life." In The New Cambridge Medieval History 3, c.900-c.1024, edited by Timothy Reuter, 186-211. Cambridge: Cambridge University Press, 2000.

McKitterick, Rosamond. "Continuity and Innovation in Tenth-Century Ottonian Culture." In Intellectual Life in the Middle Ages: Essays Presented to Margaret Gibson, edited by Lesley Smith and Benedicta Ward, 15-24. London: Hambledon, 1992.

Polheim, Karl. Die Lateinische Reimprosa. Berlin: Weidmannsche Buchhandlung, 1925.

Snijders, Tjamke. "Obtulisti libellum de vita domni Remacli: The Evolution of Patron Saint Libelli as Propagandist Instruments in the Monastery of Stavelot-Malmedy, 938-1247." BMGN - Low Countries Historical Overview 128, no. 2 (2013): 3-30.

Thomas, Sarah Fawcett. Butler's Lives of the Saints (September). Collegeville: Burns\&Oates, 2000.

Tunberg, Terence O. "Prose Style and Cursus." In Medieval Latin: An Introduction and Bibliographical Guide, edited by F. A. C. Mantello and A. G. Rigg, 111-21. Toronto: University of Toronto, 1996. 
Turcan-Verkerk, Anne-Marie. "Forme et la réforme: Le grégorianisme du Moyen Âge latin, essai d'interprétation historique du phénomène de la prose rimée latin aux xie et xire siècles." $\mathrm{PhD}$ dissertation, Sorbonne, 1995.

Webb, J. R. "The Decrees of the Fathers and the Wisdom of the Ancients in Heriger of Lobbes' Vita Remacli." Revue Bénédictine 120, no. 1 (2010): 31-58.

Wilkin, Alex, and Jean-Louis Kupper, "Introduction." In Évêque et prince: Notger et la Basse-Lotharingie aux alentours de l'an mil, edited by Alex Wilkin and Jean-Louis Kupper. Liège:

Presses Universitaires de Liège, 2013. 


\section{ABSTRACT}

The paper offers a detailed investigation of select passages from the Vita II Sancti Remacli, a hagiographic text produced in the diocese of Liège in the last decades of the tenth century. The purpose of this investigation is threefold. First, to illustrate the point that the tenth-century Latin hagiographic texts produced in the diocese of Liège did not display quotations from classical and patristic authors only as petrified forms of frozen ancient wisdom with a merely decorative function, but rather as raw gems which were polished and adjusted to fit seamlessly into a new framework. Thus, they could enhance both the form and contents of texts closely connected to their age's political and intellectual realities. Second, to show that nineteenthand twentieth-century editions of such texts can act as distorting mirrors to modern readers and researchers, since, due to an editorial strategy that privileged classical material over its medieval context, the editors sometimes completely neglected how quotations from ancient authors were re-worked by the tenth-century hagiographer following the stylistic requirements of rhymed prose. Third, to suggest as a necessary corrective to this distorting approach a new way of reading and consequently editing these types of texts, which places classical and patristic quotations in their proper context, by paying due attention to manuscript evidence, to the stylistic requirements of their new context, and to the complex functions they play in their new textual environment.

KEYWORDS: classical quotations, hagiographic discourse, Vita II Sancti Remacli, Liège, rhymed prose 
QUASI NANI SUPER HUMEROS GIGANTUM? PONOVNA UPORABA CITATOV IZ KLASIČNIH IN SREDNJEVEŠKIH AVTORJEV V HAGIOGRAFSKEM DISKURZU NA PODROČJU LIĖGA $\vee$ DESETEM STOLETJU

\section{IZVLEČEK}

Članek ponuja vpogled v izbrane odlomke iz dela Vita secunda sancti Remacli, hagiografskega besedila, ki je nastalo v škofiji Liège v zadnjih desetletjih desetega stoletja. Namen te razprave je trodelen. Najprej prikazati, da besedila, ki so nastala na področju Lièga $\mathrm{v}$ desetem stoletju, ne vsebujejo citatov klasičnih in srednjeveških avtorjev zgolj v nespremenjeni različici kot avtoriteto antične modrosti in stilistični okras, ampak kakor neobrušene dragulje, ki jih je bilo pred vključitvijo v besedilo potrebno obrusiti, da so se dovršeno prilegali $\mathrm{v}$ novo jezikovno okolje. Na ta način so citati odigrali dvojno vlogo, saj so doprinesli ne samo $\mathrm{k}$ obliki besedila, ampak tudi $\mathrm{k}$ njegovi vsebini, ki je bila tesno povezana s kulturnim in političnim ozadjem časa. Tekstno kritične izdaje tovrstnih besedil, nastale v 19. in 20. stoletju, so lahko zavajajoče, saj so na podlagi takratne prakse izdajatelji klasičnim vsebinam namenili privilegiran položaj in so zanemarili vlogo citatov klasičnih avtorjev v srednjeveških besedilih, kjer so bili ti citati podrejeni pravilom rimane proze. Zadnji del ponuja alternativen način izdaje in prikaza hagiografskih besedil $\mathrm{v}$ rimani prozi, ki citate postavi $\mathrm{v}$ pravi kontekst $\mathrm{s}$ tem, da se nasloni na tradicijo rokopisov, stilistična pravila, ki so veljala za rimano prozo, in večplastno vlogo, ki so jo citati odigrali v novem jezikovnem kontekstu.

KLJUČNE BESEDE: citati klasičnih avtorjev, hagiografski diskurz, Vita II sancti Remacli, Liège, rimana proza 